\title{
POTENTIAL FOR IMPROVING THE PROCEDURE OF INSPECTING ROAD TRAFFIC ACCIDENT BLACK SPOTS
}

\author{
Elena Kurakina ${ }^{1 *}$, Sergei Evtiukov${ }^{1}$, Jarosław Rajczyk ${ }^{2}$ \\ 1Saint Petersburg State University of Architecture and Civil Engineering \\ Vtoraja Krasnoarmeyskaya st., 4, Saint Petersburg, Russia \\ ${ }^{2}$ Częstochowa University of Technology \\ Dabrowskiego st, 69, Czestochowa, Poland
}

*Corresponding author: elvl_86@mail.ru

\begin{abstract}
Introduction: This study proves that the procedure of inspecting road traffic accident black spots (RTA BS) needs improvement. This improvement is to involve the tools and insights associated with the targeted program approach, as well as a road infrastructure indicator system, and information technology tools. The creation of a road infrastructure indicator system and its comprehensive application, coupled with analytical methods and accident prediction system methods, enables the assessment of measures aimed at reducing the number of RTAs. Accounting for information technology tools and systems (such as the digital traffic safety inquiries desk) is also necessary if traffic safety is to be organized and maintained in a systemic way. Purpose of the study: The study is aimed at finding a new approach to improving the procedure of inspecting RTA black spots. Methods: In the course of the study, we use systemic analysis, analytical methods, traffic safety evaluation based on defining the safety and accident coefficients and revealing RTA black spots, probability theory methods, research results processing, and IT computational methods. Results: We provide a rationale for a comprehensive approach to inspecting RTA black spots within the "traffic participant - vehicle - road - external environment" system. We also demonstrate how a group of parameters can be used for studying the systemic indicators of road infrastructure, in the context of the parameters' characteristics, as well as the conditions of their use. We determine the capabilities of analytical methods, as well as accident prediction methods, in the context of finding an approach to improving the procedure of inspecting RTA black spots. We propose applying a comprehensive approach to the improvement of the RTA BS inspection procedure.
\end{abstract}

\section{Keywords}

Road, road traffic accidents, road traffic safety, RTA black spot, inspection.

\section{Introduction}

Improvement of traffic safety and its systemic management is the top public policy priority, primarily because addressing this issue will help safeguard human lives and health. To reaffirm its commitment to this mission, Russia introduced Federal Law No. 196-FZ "On Road Traffic Safety" dd. December 10, 1995 (State Duma of the Russian Federation, 1995). The law, which defines road traffic safety as "activities aimed at preventing the causes of road accidents and mitigating the consequences of road accidents", has prompted the deployment of the targeted program approach (TPA), which now serves as the main principle of traffic safety measures. We interpret road traffic safety as a comprehensive and systemic set of activities. If the approach to traffic safety is randomized or non-systemic, it will not yield any viable results.

The systemic approach includes in-depth research and improvement of each element within the commonly used system: Driver - Vehicle - Road - Environment (DVRE). However, we believe that this system requires an adjustment: Traffic Participant - Vehicle - Road External Environment (TP-V-R-EE). This is necessitated by some of Russia's current official guidelines, which are aimed at reducing the number of road accidents and constitute TPA tools relevant to the following: behavior studies of TP (drivers (D), pedestrians $(P)$, underage pedestrians $\left(P_{U}\right)$, vehicle passengers $\left(P_{V}\right)$ ); analysis of vehicle $(V)$ technical condition and use; improvement of the road infrastructure and management of traffic within the external environment (R, EE); studies of interactions between the external environment (EE) factors and $T P$, vehicles $(V)$, and road $(R)$; development of a road traffic accident (RTA) victim aid and rescue system and a road traffic safety (RTS) management (Fig. 1).

The systemic approach has been used in the global practice of ensuring RTS for a long time. It takes into account multiple internal and external factors that affect the tasks and their functions (Kravchenko and Oleshchenko, 2018). The need for studying the multifactor method also serves as a rationale for developing a special approach to RTS improvement within the TP-VR-EE system - specifically, a comprehensive approach to examining high-risk road sections that may potentially become RTA black spots; this approach should also account for the specific features of the road infrastructure. 


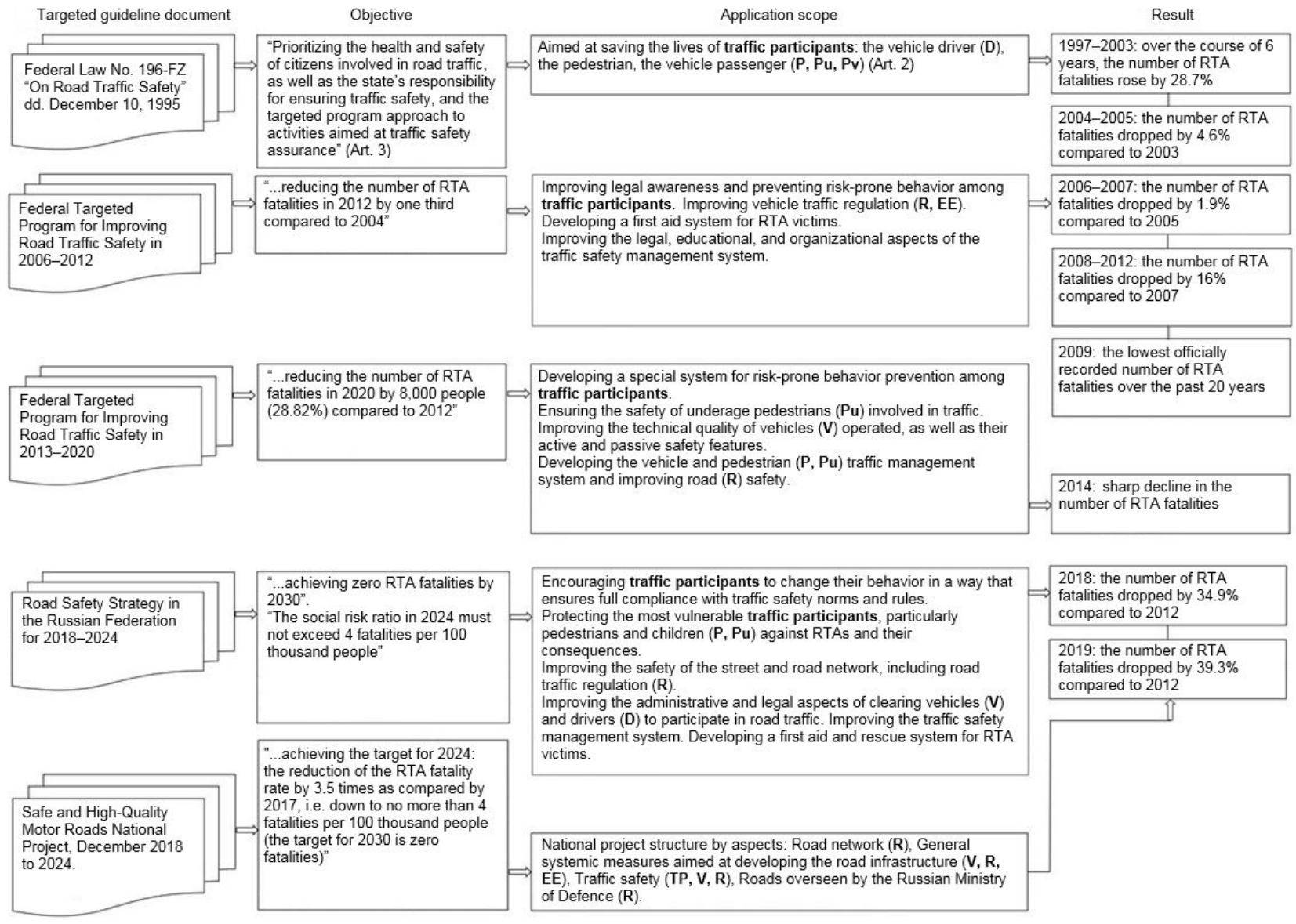

Figure 1. Targeted guidelines adopted in Russia for the purpose of reducing the road accident rate

Aside from the application of the TPA in a meaningful way that contributes to the positive dynamics of RTA reduction, the study of the system elements and RTS management is also furthered by distinguished authors, who have managed to obtain the following research and practical insights:

- systemic RTS organization and management (Kravchenko and Oleshchenko, 2015, 2018);

- methods of controlling traffic and pedestrian flows; groundwork for enhancing traffic light equipment with presignals that will facilitate traffic flow coordination; a new approach to the introduction of the left-turning section of signal control (Korchagin et al., 2015; Zhigadlo and Dubynina, 2018);

- new information on the specific ways in which the driver (D) changes vehicle (V) steering safety; discovery of reasons behind traffic safety violations (Evtjukov and Repin, 2015; Evtiukov et al., 2018);

- a scientific and educational approach to determining vehicle $(V)$ service life; developed optimization algorithms for the vehicle $(\mathrm{V})$ maintenance and repair system (Domke and Zhestkova, 2011; Kapitanov et al., 2018);
- results of studying the transport and operating conditions of roads $(R)$, including the determination of a dynamic pattern in braking and adhesion characteristics of vehicle $(\mathrm{V})$ wheels on the road surface at the stage of road operation and reconstruction (Brannolte et al., 2017; Novikov et al., 2019);

- methods of analyzing RTA and creating RTA models for the purpose of RTS improvement (Brannolte et al., 2017; Evtjukov and Repin, 2015; Kurakina, 2014);

- guidelines for conducting RTA expert analysis and improving the assessment methods and methods of examining vehicles involved in RTAs (including the technical condition of the vehicle $(\mathrm{V})$ and road $(\mathrm{R}))$, RTA BS study insights and suggestions for efficient RTS assurance (Evtyukov and Vasilyev, 2012; Kurakina, 2014, 2018; Kurakina et al., 2018, Novikov et al., 2019; Rajczyk et al., 2018).

However, the insights above were, to a certain extent, localized to very specific fields. Therefore, they do not provide tools for comprehensive qualitative assessment of the procedure of studying RTA BS as a system. This dictates a need for a systemic approach to improving the 
RTA BS inspection procedure. The inspection is not only a set of state analyses and measures targeting the TP-V-REE system but also the result of those measures, namely the reduction of the target parameter (RTA fatalities). The main goal of RTA BS inspection is a comprehensive study on the parameters that describe the condition of TP-VR-EE system elements through analytical, scientific and methodological, computational, and diagnostic means.

The existing regulatory framework reflects the inspection procedure, but the officially recommended procedure of RTA BS study does not cover the entire set of relevant factors, all the more so as RTA BS represent a system, and, therefore, call for a comprehensive systemic organization. The results of analyzing a large set of statistical data show that the overwhelming majority of RTAs in black spots are caused by traffic safety violations; nonetheless, the road infrastructure, coupled together with external environmental conditions, does make its own contribution to creating a hazardous situation, thus increasing RTA risk or making RTA consequences more severe. The regulatory framework that we referenced above limits the opportunities for studying and analyzing the causes of RTAs in black spots, which calls for a better and more efficient RTA BS inspection methodology.

\section{Subject, tasks, and methods}

The subject of this study is RTA black spots.

The tasks of the study are as follows:

- assessing the need for studying a complete set of RTA causes and factors in black spots;

- creating the elements of a comprehensive approach to improving the RTA BS inspection procedure.

In order to complete these tasks, we used analytical methods that were based on analyzing links, vectors, and timescales, as well as RTS assessment methods that were based on determining the safety and accident coefficients and pinpointing the RTA black spots, probability theory methods, study result processing, and the computational methods of information technology.

\section{Results and discussion}

Order of the Federal Road Agency (Rosavtodor) No. 105-r dd. January 31, 2017 "On the Introduction of Amendments in Industrial Road Guidance Document ODM 218.6.015-2015 'Recommendations for Accounting and Analysis of Road Accidents on the Roads of the Russian Federation', recommended for application according to Order of the Federal Road Agency No. 853-r dd. 12.05.2015", defines a "black spot" as a road/street section not exceeding $1000 \mathrm{~m}$ outside a populated area and 200 $\mathrm{m}$ within a populated area, or a road/street intersection, where three and more RTAs of the same type or five and more RTAs resulting in injuries or fatalities (regardless of type) occurred during the reporting year. ODM 218.6.0152015 and ODM 218.4.004-2009 "Guidelines on Preventing and Eliminating Road Traffic Accident Black Spots During Road Use" can be used as sources of recommendations for analyzing RTA BS. They lack a coherent procedure for inspecting RTA BS and the relevant objects that could have revealed the links and interaction vectors within the TP-V-R-EE system relevant to the black spot of each specific RTA, while also accounting for the complete set of causes and factors.

Studying the full set of RTA causes and factors in black spots is essential for an appropriate assessment of the RTS level in black spots and efficient RTS measures. In order to achieve this, we must account for the parameter groups created, and analyze them in the context of the parameters' characteristics, as well as the conditions of using the parameters in the studies of systemic indicators of the road infrastructure. Furthermore, we must refer to road accident prediction methods (Kurakina et al., 2020). An RTA BS is referred to as stable if the annual number of accidents in the relevant road section does not fluctuate by more than one or two. If the above statement is true, this points to certain persistent factors that affect the road section; these include, first and foremost, the parameters of the road infrastructure in the actual RTA BS, as well as their disadvantageous combination with the road infrastructure parameters in adjacent road sections. We are proposing a new, comprehensive approach to improving the RTA BS inspection procedure (Fig. 2), based on the following: the RTS state analysis, the TPA impact, the statistical data on accident rates within the TP-V-R-EE system, the factors and causes of hazardous traffic conditions, the developed algorithms of road infrastructure studies, RTA $B S$, information technologies and communication links, prediction methods, and study result processing.

Notably, the development of information systems and technologies has had an impact on building efficient communication links between TP and the executive authorities responsible for improving traffic safety. For instance, in Saint Petersburg, TP are making an active contribution to the development of the street and road network (SRN); during their active use of certain SRN segments, they spot their flaws and report them via the digital inquiries desk of the city Administration.

The aforementioned collaboration has allowed us to include the "digital traffic safety inquiries desk" block into our comprehensive approach; however, it may also be used as a separate element.

The practical application of research results (Evtiukov and Vasilyev, 2012; Kurakina, 2014; Kurakina et al., 2017) has resulted in greater expert evaluation quality and accuracy, while also allowing for a downward shift of the RTA BS target value. Our analysis of road accident rate statistics, as well as the key systemic indicators that we have singled out within the road infrastructure (Kurakina et al., 2020) allow for an assessment of RTS measures' efficiency.

The comprehensive approach to improving the RTA $B S$ inspection procedure in the TP-V-R-EE system covers the following:

- assessment of the accident hazard scope by means of statistically processing the number of RTAs that resulted in injuries, and the severity of these injuries, and contrasting the target values and indicators against the reference years and similar periods;

- evaluation and assessment of the TPA and the key principles of achieving accident reduction in Russia over the previous year;

- the inclusion of: tools that help achieve the TPA goals, the TPA scope, and the road infrastructure indicator 


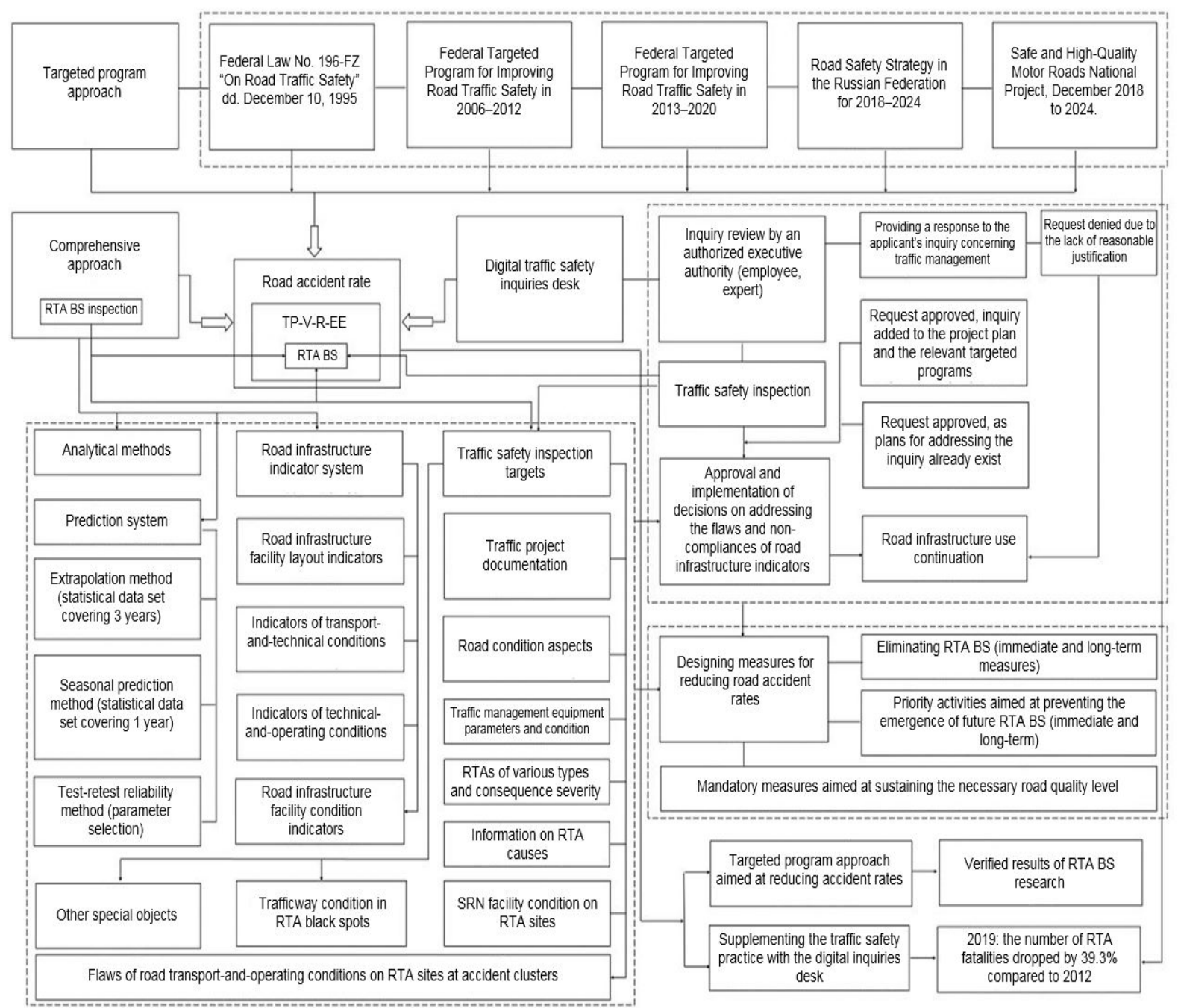

Figure 2. Comprehensive approach to the improvement of the RTA BS inspection procedure

system; the comprehensive application thereof, coupled with analytical methods and accident prediction system methods; possibly, also the inclusion of the digital inquiries desk at the organization responsible for traffic safety.

The efficiency of RTA BS inspection is defined by the following factors:

- the reference period for accident rate evaluation at the road sections analyzed;

- the use of scientific, analytical and computational methods for analyzing and processing the data on road infrastructure facilities' parameters;

- the use of diagnostic equipment for obtaining accurate data on road infrastructure facilities' parameters;

- the validity of regulatory documents establishing procedures for RTA BS inspection.

We recommend using two alternative criteria for selecting sets of RTS measures at RTA BS:
- whether or not the relevant measures have helped meet target accident rate reduction value at a minimal cost;

- whether or not the relevant measures have helped meet target minimal accident damage value at a minimal cost.

As for deploying the measures aimed at reducing accident rates in the conditions described, we recommend a step-by-step approach.

The results of efficiently applying the set of measures include: finding inconsistencies between the layout and features of the road infrastructure facilities and transportand-technical / technical-and-operating conditions, on the one hand, and the current regulations and technical specifications, on the other hand; determining accident causes and factors relevant to black spots; designing impactful administrative solutions and measures for 
eliminating RTA BS (immediate and long-term) and priority activities aimed at preventing the emergence of future RTA BS (immediate and long-term); offering recommendations on mandatory measures aimed at sustaining the necessary road quality level, in line with the current regulations and technical specifications.

\section{Conclusions}

The organization of work to identify and eliminate RTA BS is a significant resource for reducing road accident rates and improving RTS. Studying a set of causes and fact causes and factors that define RTAs in black spots is founded on a qualitative assessment of the RTS level and accident trends in black spots, as well as on the opportunity to conduct a comprehensive study that accounts for the full set of RTA causes and factors. The use of a comprehensive approach to improving the RTA BS inspection procedure is a non-binding recommendation, and the inspection approaches that we have used highlight the potential for further improvement. 


\section{References}

Brannolte, U., Chubukov, A., Kapitanov, V., Monina, O. and Silyanov, V. (2017). Simulation of regional mortality rate in road accidents. Transportation Research Procedia, 20, pp. 112-124. DOI: 10.1016/j.trpro.2017.01.031.

Domke, E. R. and Zhestkova, S. A. (2011). Probabilistic model brakes wheeled vehicles. The World of Transport and Technological Machinery, 2, pp. 3-7.

Evtiukov, S., Karelina, M., Terentyev, A. (2018). A method for multicriteria evaluation of the complex safety characteristic of a road vehicle. Transportation Research Procedia, 36, pp. 149-156. DOI: 10.1016/j.trpro.2018.12.057.

Evtiukov, S. A. and Vasilyev, Ya. V. (2012). Road accidents: investigation, reconstruction, expert examination. Saint Petersburg: Publishing House DNK, 392 p.

Evtjukov, S. and Repin, S. (2015). Renewal methods of construction machinery according to technical and economic indicators. Applied Mechanics and Materials, 725-726, pp. 990-995. DOI: 10.4028/www.scientific.net/AMM.725-726.990.

Kapitanov, V., Silyanov, V., Monina, O. and Chubukov, A. (2018). Methods for traffic management efficiency improvement in cities. Transportation Research Procedia, 36, pp. 252-259. DOI: 10.1016/j.trpro.2018.12.077.

Korchagin, V. A., Lyapin, S. A., Klyavin, V. E. and Sitnikov, V. V. (2015). Improving traffic safety based on emergency analysis and road accident emulation. Fundamental Research, 6, pp. 251-256.

Kravchenko, P. A. and Oleshchenko, Ye. M. (2015). Concept of complete observability in systems preventing road traffic injuries. Transport of the Russian Federation, Special Issue, pp. 25-31.

Kravchenko, P. A. and Oleshchenko, Ye. M. (2018). Systemic approach to managing traffic safety in the Russian Federation. Transport of the Russian Federation, 2, pp.14-18.

Kurakina, E. V. (2014). Scientific and methodological support of vehicle expert examination taking into account the technical condition of the vehicle and road environment. PhD Thesis in Engineering. Saint Petersburg: Saint Petersburg State University of Architecture and Civil Engineering.

Kurakina, E. V. (2018). On the effectiveness of studies carried out at places of road traffic accident concentration. Bulletin of Civil Engineers, 2, pp. 231-237. DOI: 10.23968/1999-5571-2018-15-2-231-237.

Kurakina, E., Evtiukov, S. and Ginzburg, G. (2020). Systemic indicators of road infrastructure at accident clusters. Architecture and Engineering, 5 (1), pp. 51-58. DOI: 10.23968/2500-0055-2020-5-1-51-58.

Kurakina, E. V., Evtiukov, S. S. and Golov, E. V. (2017). Reconstruction of road accidents: monograph. Saint Petersburg: Petropolis Publishing House, 204 p.

Kurakina, E., Evtiukov, S. and Rajczyk, J. (2018). Forecasting of road accident in the DVRE system. Transportation Research Procedia, 36, pp. 380-385. DOI: 10.1016/j.trpro.2018.12.111.

Novikov, I. A., Kravchenko, A. A., Shevtsova, A. G. and Vasileva, V. V. (2019). Scientific-methodological approach to reduce accidents on the roads of the Russian Federation. World of Transport and Technological Machines, 3, pp. 58-64. DOI: 10.33979/2073-7432-2019-66-3-58-64.

Rajczyk, P., Kurakina, E. and Knapiński, M. (2018). The influence of surface topography on the safety of road and utility surfaces. Transportation Research Procedia, 36, pp. 640-648. DOI: 10.1016/j.trpro.2018.12.139.

State Duma of the Russian Federation (1995). Federal Law No. 196-FZ "On Road Traffic Safety" dd. December 10, 1995 (as amended on December 27, 2018).

Zhigadlo, A. P. and Dubynina, M. G. (2018). Influence of the psychophysiological traits of drivers on safe driving. Vestnik Sibirskogo Otdeleniya Akademii Voennykh Nauk, 49, pp. 119-130. 


\title{
ПОТЕНЦИАЛ СОВЕРШЕНСТВОВАНИЯ МЕХАНИЗМА АУДИТА МЕСТ КОНЦЕНТРАЦИИ ДТП
}

\author{
Елена Владимировна Куракина ${ }^{1 *}$, Сергей Аркадьевич Евтюков ${ }^{1}$, Ярослав Райчык² \\ ${ }^{1}$ Санкт-Петербургский государственный архитектурно-строительный университет \\ 2-ая Красноармейская ул., 4, Санкт-Петербург, Россия \\ 2Ченстоховский политехнический институт \\ Домбровского ул., 69, Ченстохова, Польша \\ *E-mail: elvl_86@mail.ru
}

\begin{abstract}
Аннотация
Обоснована необходимость совершенствования механизма аудита мест концентрации дорожнотранспортных происшествий (МК ДТП). Потенциал совершенствования заключается в приеме учета механизмов достижения результатов программно-целевого подхода и направления их реализации, системы индикаторов дорожной инфраструктуры, инструментов информационных технологий. Разработанная система индикаторов дорожной инфраструктуры в комплексном применении с аналитическими методами и методами системы прогнозирования аварийности позволяет оценить мероприятия, направленные на сокращение числа ДТП. Прием учета инструмента информационных технологий и систем - электронной приемной организации безопасности дорожного движения необходим для разработки системной организации и управления уровнем безопасности дорожного движения (БДД). Цель исследования: Разработка подхода к совершенствованию механизма аудита мест концентрации ДТП. Методы: Системный анализ, аналитические методы, методы оценки БДД на основе выявления коэффициентов безопасности и аварийности, выявления мест концентрации ДТП, методы теории вероятности и обработки результатов исследования, программно-вычислительные методы информационныхтехнологий. Результаты: Обоснована эффективность комплексногоподхода кисследованию мест концентрации ДТП в системе «участник дорожного движения - транспортное средство-дорога-внешняя среда». Обосновано применение группы показателей в системе их параметрических характеристик и условий использования для исследования системообразующих индикаторов дорожной инфраструктуры. Определены возможности аналитических методов, методов прогнозирования дорожной аварийности для разработки подхода к совершенствованию механизма аудита мест концентрации ДТП. Предложен комплексный подход совершенствования механизма аудита МК дТП.
\end{abstract}

Ключевые слова

Автомобильная дорога, дорожно-транспортные происшествия, безопасность дорожного движения, место концентрации ДТП, аудит. 